\title{
Vad som kan hända då man installerar ny webbläsare, gärdsgårdar ruttnar och om fnyxar i allmänhet.
}

\author{
Av Per Flensburg, docent i Informatik
}

Häromdagen hämtade jag hem den senaste versionen av Netscape (ver 4.06). Största anledningen var en ny liten knapp "related sites" som enligt utsago letar reda på sidor som påminner om den man är på. Och mycket riktigt, efter ett tag hittade den två andra ställen, som var relaterade till min hemsida http://www.masda.vxu.se/ per/index.html, nämligen ett inlägg som Bo Dahlbom, professor i informatik i Göteborg, hade gjort på konferensen Sanning \& Konsekvens och som jag i ett svar hade häftigt kritiserat. Och så fanns det en länk till humanistiska institutionens hemsida. Intet mera.

Det gjorde mig naturligtvis nyfiken. Själv ser jag förstås uppenbara kopplingar mellan mitt eget ämne, informatik, och diverse humanistiska ämnen. Men att en dum webbläsare gör sammalunda, det förvånade mig. Men sagt och gjort, jag klickade på länken till humanistiska institutionens hemsida och kom till en helt perfekt intranetsida! Allt var samlat på ett ställe, redigt och ordentligt uppställt och med god överblick. OK, ska man nu se på de regler som gäller för marknadsföring och utförsäljning av sitt budskap, så bröt man nog mot de flesta av dessa regler, en utifrån kommande, tillfällig besökare överger nog stället tämligen snabbt. Men hemsidorna är väl främst gjorda för internt bruk och då var den här helt idealisk. Jag lyckades t.ex. inom 15 sekunder att sätta upp mig på mailinglistan till GramTime News!

På denna sida hittade jag en nät-tidning, HumaNetten, som jag naturligtvis klickade på och hittade genast en oerhört intressant artikel av Jonny Nilsson och Kenneth Strömberg, båda doktorander i historia. Det var en fascinerande artikel, speciellt som den tog upp saker jag själv gått och funderat över de senaste 10 åren. Därför vill jag gärna, efter fattig förmåga, kommentera detta verk.

Om jag fattat budskapet rätt, så menar Jonny och Kenneth att dagens forskning ofta sysslar med meningslösheter och trivialiteter och att forskarna inte gör sin egen roll i samhället tillräckligt klar för sig. Det kommer mig att tänka på begreppet "fnyx".

Understundom frågar jag mina studenter om de vet vad en "fnyx" är. Naturligtvis vet de inte det. Efter en del lirkande kommer vi fram till att

1. Ett begrepp definieras genom sina egenskaper.

2. "Fnyx" har inga egenskaper.

Det sista förtjänar måhända en del kommentarer. Om man frågar vad fnyx har för färg, så är den frågan meningslös, eftersom fnyx inte har egenskapen "färg". Lika meningslöst som det är att fråga efter färgen på mina tankar, lika meningslöst är det att fråga efter färgen på en fnyx. Lika meningslöst som det är att fråga efter hur många kilo TV:s väderrapport väger, lika meningslöst är det att fråga efter hur mycket fnyxen vägen. En fnyx har inga egenskaper, den är tommare än tomma mängden (ty denna har åtminstone egenskapen att vara tom), meningslösare än en dragning i Bingolotto och innehållslösare än en svensktoppsschlager, ja fnyxen är i sanning ett meningslöst begrepp!

På detta viset går jag på en god stund och mina studenter inser hur riktigt tom, innehållslös och meningslös fnyxen är. Men så brukar någon klipsk människa inse att jag faktiskt har stått och ljugit en lång stund. Fnyxen är inte utan egenskaper, ty den har ju ett namn! Tack vare denna meningslösa bokstavskombination kan jag stå och hålla låda för mina studenter och i både bokstavlig och bildlig mening tala om absolut ingenting! Fascinerande! Därefter brukar jag berätta om skillnaden mellan data, information och kunskap, men här ska jag istället hävda att mycken forskning är till sin 
natur fnyxisk, den handlar om egentligen ingenting, om meningslösa bokstavskombinationer, som blir intressanta just genom att man skriver om dem med ett sådant glödande seriöst allvar! På vilket vis blir världen lyckligare om jag hittar en ny metod att beräkna Halshells delta på? Eller om jag räknar ut att färgen "blå" i programlistor bör förkortas "bl"? Eller att Strindberg i Röda Rummet skrev "Ångbåtsaktiebolaget Triton" på 13 ställen?

Grundfelet är att vetenskapen, som system betraktat, är ett av de mest slutna system som finns. Vetenskapsmän skriver för andra vetenskapsmän (och det gäller kvinnor också!), vetenskapsmän bedömer kvaliteten hos annan vetenskap, vetenskapsmän bedömer vilka andra vetenskapsmän som ska ha forskningsanslag. Hur många ickeforskare läser de tusentals vetenskapliga tidskrifter som förbrukar vår skog? Och hur många av dem som eventuellt läser artiklarna bryr sig om dem? Ska man döma av olika citationsindex, så är det endast ett fåtal procent av denna publiceringsflod som över huvud taget läses. Men hur många miljoner läggs ner på att ta fram innehållet och att sprida eländet ut över världen? Är det detta som är det yttersta tecknet på mänsklighetens framsteg?

Jag uppfattar det så att författarna efterlyser den vishet som gör att forskarna låter bli att bruka skattebetalarnas pengar på dessa meningslösheter. Och det är ett lovvärt syfte, frågan är bara vem som avgör meningsfullheten. Fast om jag förstått er korrekt är det just den diskussionen ni efterlyser. Som det ser ut nu är det vetenskapssamfundet som sätter sina egna regler. Detta görs för att, i enlighet med Lakatos teorier om forskningsprogram, beskydda vetenskapens innersta hårda kärna (som ni så riktigt påpekar, är ganska rutten) och skydda den från angrepp utifrån. Tänk bara på turerna kring vår universitetsutnämning och ni har ett utmärkt exempel på det vetenskapliga samhällets ynkedom!

Om det är vist vet jag inte, men er artikel fick mig att leta fram Aristoteles Nichomenska etik på min hårddisk och återigen börja leta i bok VI om vad han säger om phronesis (eller "wisdom" som det heter i min engelska översättning). Får se vad det leder till.

Jag konstaterar också att denna artikel, om den blir publicerad, i högskolans belöningssystem ger mig 2 poäng. Hade jag istället fyllt den med hänvisningar till andra stofi.. förlåt, vetenskapsmän, skrivit den på engelska och lyckats övertala någon utländsk tidskrift att publicera den så hade jag fått 40 poäng, lika mycket som när jag skriver en 500 sidor tjock bok eller avlägger doktorsexamen! Hur många människor hade läst mitt opus då? Hur många hade reagerat? Hade någon av er, kära läsare av HumaNetten, kommit i åtnjutande av detta? Hade någon av er nånsin reagerat? Förvisso inte, men genom denna enkla och anspråkslösa publiceringsform når jag min målgrupp, jag kanske lyckas provocera någon mer till att yttra sig, kanske rent av någon börjar tänka efter. Är det inte detta som är forskningens och vetenskapens innersta väsen och yttersta mening: Att få oss till att tänka! Borde inte Växjö universitet premiera vishet istället för vetenskaplighet? Skulle inte det kunna vara en av våra profiler?

(C) Per Flensburg 